\title{
Academic Pathways to University Leadership: Presidents' Descriptions of Their Doctoral Education
}

\author{
Sydney Freeman, Jr. \\ Tuskegee University, \\ Tuskegee, Alabama, USA \\ sfreemanjr@mytu.tuskegee.edu
}

\author{
Frances K. Kochan \\ Auburn University, \\ Auburn, Alabama, USA
}

kochafr@auburn.edu

\begin{abstract}
The purpose of this study was to examine university presidents' perceptions of their academic doctoral preparation program as it related to their preparation for the university presidency. Using a mixed methods approach, thirteen presidents shared what knowledge and competencies they perceived as having learned while in their doctoral program. The areas of knowledge they believed they developed were foundational knowledge, knowledge acquisition of context, and complex cognitive knowledge. The four competencies areas they believed they refined in their programs were interpersonal development, personal attributes, management, and communications. They identified fund-raising as an area they were not well prepared for.

The results of this study should help administrators, curriculum developers, and faculty in higher education administration programs to better understand higher education students' needs and enhance their programs. In addition, it should provide information about whether and how professional development, mentoring, and coaching activities within these programs help in preparing individuals for executive leadership and ensuring their success.
\end{abstract}

Keywords: University Presidency, Doctoral Education, Higher Education Programs, Life History Case study.

\section{Introduction}

Although individuals come to the presidency from a variety of environments, over $40 \%$ of college and university presidents have earned a doctoral degree in either education or higher education (American Council of Education [ACE], 2007). Graduate school is seen as a powerful force that not only structures the mind, but also helps to shape the facts one legitimizes and how one interprets ideas (Brown, 2008). Dressel and Mayhew (1974) conducted the seminal research on the

Material published as part of this publication, either on-line or in print, is copyrighted by the Informing Science Institute. Permission to make digital or paper copy of part or all of these works for personal or classroom use is granted without fee provided that the copies are not made or distributed for profit or commercial advantage AND that copies 1) bear this notice in full and 2) give the full citation on the first page. It is permissible to abstract these works so long as credit is given. To copy in all other cases or to republish or to post on a server or to redistribute to lists requires specific permission and payment of a fee. Contact Publisher@,InformingScience.org to request redistribution permission. degree to which graduate programs prepared administrators for positions in higher education. They concluded there was no empirical evidence to support the notion that higher education programs prepared these administrators any better than programs in other disciplines. 


\section{Purpose and Research Question}

The purpose of this study was to examine university presidents' perceptions of their academic doctoral preparation program as it related to their preparation for the university presidency. Although graduate student expectations and preparation for executive leadership in higher education have been studied as separate research topics, there is a lack of research that has addressed these topics collectively (Baliles, 2006; Stuver, 2006). This study extends and enhances the existing research by investigating the question: "What are the perceptions of college and university presidents of the adequacy of their doctoral training in preparing them for their role at the university level?"

\section{Higher Education and the University Presidency}

The role of the president is both substantive and symbolic. These individuals speak and represent multiple constituencies associated with the university. As the individual who speaks on behalf of the institution to the Board of Trustees, the university president is also in charge of assuring that trustees are involved in the planning processes, assume ownership of the plan, and receive regular feedback on its progress (Luxton, 2005).

University presidents come from a variety of academic backgrounds. It is important to note that there is no degree that places a person on a linear track to the presidency. What is generally recognized is that graduate education plays a vital role in developing academic leaders. Graduate degrees signal to potential employers that the candidate understands the values of academia. Selingo (2003) writes, "Frankly, academic credentials are important in this business" (p. A40).

Lester Goodchild (2002) defined higher education as a field of study that included "sophisticated knowledge about and research on colleges, universities, and related postsecondary institutions, as well as the professional skills used by those persons who work in them" (p. 303). He describes the purpose of higher education programs as to "educate and train professionals for administrative, faculty, student life, and policy analyst positions in the country's approximately 4,000 postsecondary institutions" (p. 303).

The field of higher education has developed over the last 100 years. Barnett (2007) describes the major reasons that the field developed as (1) the emergence of institutional history and the development of institutional research, (2) the counseling, testing, and guidance movements, (3) the emergence of national, regional, and local commissions, and (4) the presence of an emerging group of individuals who considered themselves student and scholars of higher education.

The confluence of these factors along with the strong interest of G. Stanley Hall in the late 1800s prepared the way for higher education to emerge as a field of study. Hall, the president of Clark University at the time, developed the first course in higher education studies in 1893. Later, he created a 16-course specialization that became a part of the Ph.D. program in education at Clark University (Barnett, 2007). This continual focus on higher education as a means of preparing leaders for positions in administering institutions of higher learning inspired other larger institutions such as Ohio State University, Columbia University's Teachers College, the University of Chicago, the University of Pittsburg, the University of California, Berkeley, and the University of Michigan to develop graduate programs in the field of higher education during the early $1900 \mathrm{~s}$ (Wright, 2004).

Several executive higher education doctoral programs have sprouted during this decade. Among them are programs at the University of Pennsylvania, University of Alabama, University of Georgia, and Jackson State University. Most of these programs are arranged in a cohort model and students must demonstrate that they have performed substantial leadership throughout their careers to gain admittance. The program usually takes two to three years for students to com- 
plete. It appears that Jackson State University is the only one of these programs that offers a Ph.D. The other programs offer an Ed.D. Doug Toma at the University of Pennsylvania was the founder of the first university executive leadership program in the United States. In an interview with Selingo (2003) Toma said he founded this program because there were few programs catering to top college officials who wanted to earn a doctorate quickly without taking time off from their jobs. Therefore, he and his institution developed this program option. Toma went on to say, "In admitting a class, faculty members seek applicants who are one step away from becoming presidents" (p. A40).

\section{Research on Higher Education Programs}

Higher education programs have been studied extensively by scholars in the field of education over the last 40 years (Altbach, Bozeman, Janashia, \& Rumbley, 2006; Barnett, 2007; Dressel \& Mayhew, 1974; Fife \& Goodchild, 1991; Kienle \& Loyd, 2005; Wright \& Miller, 2007). And there are also many researchers who have investigated the role of doctoral education in preparing students for the academy (Austin, 2002; Ellis, 2001; Gardner, 2010, Gonzalez, 2006; Haynes, Bulosan, Citty, Hudson, \& Koro-Ljungberg, 2012; Holley, 2011; Leech, 2012; Soto-Antony, 2002; Weidman, Twale, \& Stein, 2001). In particular, there are many studies that address the role that higher education programs play in the development of community college leaders (Hammons \& Miller, 2006; Herdlien, 2004; Keim, 1991) and student affair practitioners (Keim, 1991;

Sandeen 1982). However, there is still little research on their value in terms of preparing individuals for the university presidency. Changing circumstances make this issue more critical than in the past.

In prior years, it was most common that higher education graduates were offered lower- and middle-level management positions in colleges and universities, as well as careers in government agencies dealing with higher education, think tanks, and related jobs. In recent years, however, higher education graduates have earned upper management positions including presidencies more frequently upon graduation (Altbach \& Enberg, 2001, p. 15).

Although higher education programs prepare potential higher education administrators, faculty, and policy makers, there are no common requirements or core course requirements for these doctoral students. Historically, the curriculums of these programs have been centered on the expertise of the faculty and anecdotal evidence provided by administrators and faculty (Bray, 2007). It is essential that higher education doctoral programs begin to develop standards and curriculum that reflect the needs of a growing higher education workforce based upon the perceptions of graduates of those programs (Wright, 2007).

In 2006, the Council for the Advancement of Standards in Higher Education (CAS) adopted a set of student affairs master's level preparation standards. In addition, in 2010, the Association for the Study of Higher Education's Council for the Advancement of Higher Education Programs adopted set of guidelines for Higher Education Administration and Leadership Preparation Programs at the master's degree level. However, there are no guidelines or standards that address higher education leadership doctoral programs. This study helps to fill that void by examining perceptions of the value of these programs in preparing university presidents.

\section{Methods}

The research used a mixed-methods approach involving quantitative and qualitative data collection. The study was conducted in two phases. Phase-one used quantitative methods to identify the sample population and to examine the degree to which their programs were perceived as preparing them for the presidency based on previous research. This information was used to develop 
interview questions for the study. Phase two of the study involved the use of qualitative methods to gather data needed to address the research questions posed.

\section{Phase One-Quantitative Analysis and Population and Sample Selection}

The initial research phase involved analyzing quantitative data from a 50 question survey on the presidency, provided by the American Council of Education's (ACE) study published as The American College President: 2007 Edition (ACE, 2007). The study gathered data from 2,148 presidents to identify the degree to which these presidents perceived they were prepared for their role prior to assuming it. In the ACE study, the population included presidents with terminal degrees in a variety of fields, both from within and outside of education. There were 2,148 presidents who participated in this study. Of these, 891 identified themselves as having earned a terminal degree in education or higher education. The study did not differentiate between those who had earned doctorates in education with specializations other than higher education in the data analysis. Therefore, there was no way to distinguish between the responses of those who were graduates of higher education programs and those who were not.

The ACE study (see Appendix A) included the question, "In which of the following areas did you feel insufficiently prepared for your first presidency?" The question included 17 variables. These competencies have been identified, developed, and refined over 20 years through interviews and feedback from college and university presidents (ACE, 2007; J. King, personal communication, September 4, 2010). The presidents were able to check all areas that applied.

A chi-square analysis was conducted to determine if there were differences between how presidents with education degrees and those who had earned their degree in a different field responded. Findings indicated that presidents with a terminal degree in education/higher education felt statistically significantly more prepared for enrollment management duties (ACE Question 35 item 8) versus presidents who held a terminal degree outside of education $\left(X_{(1, N=891)}^{2}=14.704, p\right.$ $<.001)$. However, these presidents believed they were statistically significantly less prepared for fundraising (ACE Question 35 item 11) than presidents who held a terminal degree outside of education $\left(X_{(1, N=891)}^{2}=9.274, p=.002\right)$.

In addition to the chi-square analysis, a one-sample t-test was used to determine the mean difference between the sample (presidents with a doctorate in education or higher education) and the known value of the population mean (presidents with a doctorate other than education or higher education). The number of items measuring the dependent variable was 17 . In this analysis, presidents with doctorates in education or higher education felt more prepared than presidents with doctoral backgrounds in other disciplines in the areas of accountability/assessment of student learning and enrollment management. Presidents with doctorates in education or higher education felt less prepared than presidents with doctoral backgrounds in other disciplines in the area of fund raising.

The findings from both of these analyses were used to develop interview questions used in phase 2. They were also used in the developing initial "a priori" questions as part of the grounded theory process used in the case study conducted to address the research question posed.

\section{Phase Two-Qualitative Process}

The second phase of the study involved qualitative data collection. The researcher incorporated the Life History Case Studies (LHCS) approach to collect the data. LHCS is a qualitative methodology specifically designed to assist researchers in understanding the in-depth and comprehensive meanings in people's lives and helps them to gather background information about the study participants (Campbell, 1999). This method allowed an exploration of the participants' percep- 
tions of their graduate training in higher education administration and its role in preparing them for their current position. This approach was also used to explore what knowledge and competencies they perceived as having learned while in their doctoral program.

The population was derived from the 1,647 college and university presidents who are members of the American Council of Education, as identified on their organizational website (American Council of Education, 2010, para. 1). Of this group, 150 presidents who had earned a degree with a specialization in higher education administration were leading institutions using the term "university" in their nomenclature.

After being solicited via email or phone to participate in this study, thirteen of the 150 presidents agreed to participate. These presidents included three females and ten males. Three African American presidents participated in the study that also happened to serve as leaders of Historically Black Universities. The ten other presidents were Caucasian and led Predominantly White Universities. Five presidents led private religious institutions. The eight remaining presidents served public universities. The presidents led institutions whose student enrollment ranged from less than 2,000 to more than 50,000 students. Pseudonyms are used in this manuscript instead of the presidents' names to keep their responses anonymous.

The primary data source of this study was interviews. Two guided interviews were conducted with each president, and university presidents were asked key questions about their doctoral training (see Appendix B). This process provided rich data, which assisted in interpreting the responses and developing the information into a meaningful narrative.

Before each interview began, permission was gained using the Auburn University Institutional Review Board approved informed consent form to audio and video record the interviews. Both what the presidents said (i.e., their words and language) and what was unsaid (i.e., body language and long pauses) were considered when logging notes. The study incorporated a process that included conducting interviews and reviewing of the presidents' curriculum vitas and biographical sketches, a process advocated by Gasman and Anderson-Thompkins (2003).

\section{Coding and Data Analysis Process}

Multiple data sources were used to confirm the study's results (Yin, 2003). Field notes written during participant interviews, ideas developed during the research process, audiotaping, and videotaping the interviews served as the sources for analysis. A start list of 80 "a priori" codes was derived from related literature on higher education programs and presidential leadership. Themes that not derived from the start list, identified in the data, were coded as emerging codes. The "coding incident to incident" approach advocated by Charmaz (2006) was used throughout the analysis process. This provided the opportunity to compare similar incidents experienced by various participants. Similar emergent codes were combined with one another to limit the amount of redundant codes.

\section{Concerns for Internal/External Validity, Reliability, and Generalizability of Results}

In order to heighten content validity, three senior academic administrators and faculty reviewed pilot questions (Ross \& Shannon, 2008). Revisions were made based on this expert panel's feedback. Pilot field interviews were then conducted with six academic administrators. In addition, two focus group interviews were conducted using the interview questions. The focus group members included both higher and adult education faculty and higher education administration doctoral candidates. 
After concluding the interviews with the presidential participants, follow-up email interviews were conducted for purposes of member checking and data validation. Wolfe (2010) defines member checking as "a term used to determine the trustworthiness of the data analysis." Member checking allowed the presidents the opportunity to review the information from the previous interview to ensure that it accurately reflected the presidents' feelings and responses (Creswell, 1998; Wolfe, 2010). The second interview also enabled the researcher to conduct additional questioning related to the responses from the initial interview and clarify any issues that were unclear.

\section{Limitations of the Methodology}

There are limits to the generalizability of the results of this study. The limited sample size disallows for the application of results to populations other than university presidents who have earned doctoral degrees in higher education administration. It also may not be generalizable to the perceptions of all presidents in all types of institutions classified as universities. However, it provides a foundation upon which to engage in curriculum, discussion, and further research.

\section{Presidents Descriptions of their Doctoral Education}

When asked to describe their perceptions of the degree to which their doctoral programs prepared them for the presidency, the respondents indicated that their programs had equipped them with abilities in two major areas: knowledge and competencies. These are described in detail in the sections that follow.

\section{Knowledge}

In this study knowledge is defined as (1) higher education expertise acquired by a person through experience or education; the theoretical and/or practical understanding of a subject in higher education; (2) what is known in a particular field or in total; (3) facts and information needed for executive leadership in higher education administration ("Knowledge," n.d.). Core knowledge areas that presidents identified as part of their doctoral programs, which prepared them for the presidency, were: Foundational Knowledge (History of Higher Education and Finance), Knowledge Acquisition (Subject Matter Mastery, Knowledge Application) and Complex Cognitive Knowledge (Integrate Complex Ideas, Intellectual Flexibility). These are displayed in Table 1.

Table 1: Knowledge Areas

Knowledge

Foundational Knowledge

- History of Higher Education

- Finance

Knowledge Acquisition

- Subject Matter Mastery

- Knowledge Application

Complex Cognitive

- Integrate Complex Ideas

- Intellectual Flexibility 


\section{Foundational Knowledge}

The first knowledge area derived from this study is foundational knowledge. Foundational knowledge is defined in this study as information provided to students of higher education doctoral programs that enable them to have a basic understanding of higher education as a field of study. Almost all presidents who participated in this study mentioned the effective role that foundational knowledge played in their development as a higher education professional. For example, President William James shares how his program expanded his basic knowledge of education.

What the program did for me, it introduced me to a set of literature that was very important for me... the literature on higher education, especially with respect to administration, leadership and higher education. (Because of the program) I have a very good understanding of the literature and with that understanding, learning additional leadership tactics and strategies. In particular observing or reading or learning about presidents ... leaders.

\section{History of higher education}

The first foundational area that presidents viewed as preparing them for the presidency was the history of higher education. Six presidents mentioned its importance in their intellectual development. Several of the presidents came from backgrounds outside of academia and they believed that gaining an understanding of the history of higher education helped them to appreciate the field and "tell the story" of their institution in the context of broader academia. Peter Johns, president of Ethansville University, a small private religious institution in the Southeast region of the United States, shared:

I've relied a lot on what I learned about the history of higher education and kind of the way that programs have evolved.

Johns went on to share that his knowledge of higher education helped him to understand the richness of institutions such as community colleges, although his career did not lead him to serve in that institutional type.

Emelia Lily, a president of a small public university in the Northeast region of the United States, shared that her doctoral program helped her make mental connections between her current responsibilities and the historical role of higher education. She shared,

In terms of the doctoral program, what my courses in the history of higher education gave me...was an understanding of how higher education is organized, how it works, sometimes how it doesn't work, and also gave me an understanding that you don't work in isolation in particular when you work in a system.

Many of the presidents, such as Levi Carter, perceived that gaining an understanding of the history of higher education provided them with a broader understanding of the higher education industry.

I have more of a sense of the history of higher education because of my study, more of a sense of the people who have come before me in the industry in the history of higher education and the contributions that we could all make, but I don't think I would have that perspective without the study

\section{Finance of higher education}

In addition to being in agreement about the value of gaining knowledge of the history of higher education, 11 of the respondents mentioned that being exposed to information on budgeting and 
finance proved invaluable. President Peter Johns shared that understanding financial models and budgeting helps him in managing his institution. He believes that although he has a vice president of finance, his name is on the line as president and, thus, he must have a good understanding of how his institution's budget is being managed. President Ryan Wyatt of Micah-Henry University expressed it best when he shared:

Well, I think that some of what I learned about finance and about theoretical models that are applied to finance and higher education has helped prepare me for this role, especially the revenue theory of cost.

Presidents, such as Dr. Elijah Alexander, not only gained an understanding of how budgets work in the program, he also learned how to read a budget sheet. He stated:

I can kind of drill down a budget and really see how we are allocating those resources and put in procedures and models to kind of move us where we need to be. I can find a penny; I can find a penny in a budget.

\section{Knowledge Acquisition of the Context}

The second knowledge area derived from this study is acquisition of context. Knowledge acquisition of context has two aspects - one is subject mastery, and the other is application of the knowledge. Knowledge acquisition of context is defined in this study as gaining information that enables graduates to have a basic understanding of the historical and modern context of the field of higher education. It also involves gaining the ability to find that information and applying it in real world situations. This knowledge area is a precursor to higher education competency.

\section{Subject matter mastery}

Many of the presidents expressed deep appreciation for having programs that provided them with essential concepts about the context of higher education, which is needed to be successful in higher education leadership. In addition, seven presidents spoke specifically about various aspects of knowledge, such as an understanding of the knowledge and culture of the academy, that they acquired as a result of their program. President Jessica Elliott had served many years as a principal of a religiously affiliated high school before being invited to serve as a president. After accepting the presidency she enrolled in a higher education program. She believes that her program helped her acquire the understanding of how to navigate and lead within the academy.

I learned about the culture of higher education, because I surely didn't know it, but when I went to Global University, I learned a lot about governance, about leadership of a small college as opposed to other levels of high school. I learned about how to deal with faculty, how to develop a college or university, how to interact with people, it really helped me.

In her response, Dr. Elliott displays what many presidents within the study expressed, which was an acquisition of knowledge that went further than just learning facts about the culture and context in a theoretical manner, but instead gaining a deeper understanding of the cultural and contextual elements within the higher education setting. After acquiring this knowledge, these presidents sought to master it and then incorporate it within their work.

\section{Knowledge application}

Presidents such as Emelia Lily shared that they gained a deep understanding of the context of higher education in their doctoral programs. In addition, these presidents emphasized that many of the concepts introduced in their program inform their current work and decision-making. There was a common recognition from the presidents that it was important for presidents to un- 
derstand the local context before attempting to make large institutional change. Presidents also shared that, because of the opportunities to study multiple theories and viewpoints in higher education, they were able to identify connections between seemingly juxtapositions. Lily expressed it this way:

Some of the things I learned in my doctoral program helped me to be able to see the connections and to see how things may be different, but also how things may be the same.

Dr. Emelia Lily also shared how the knowledge she acquired in her program influences her in her position as president.

I think the skills and the knowledge and the ability, it's not just skills, you know being confident, knowing that I know how to find information, knowing that I don't know everything and knowing who to call on or how to get additional information to be able to solve an issue.

Dr. Evelyn Aurora also provided a perspective on how her doctoral program helped her acquire the knowledge about how an institution should operate.

I think my higher education degree made me step back, get out of the story-telling mode where you focus on the individual and the tragic flaws and all of that, but to look back and look at institutional action and how an institutional action has to be disciplined and influence. It has to have integrity and the institution has to more or less act the same way in the same circumstances so that the quality of the product is the same.

\section{Complex Cognitive Thinking}

The third knowledge area derived from this study is complex cognitive thinking. Complex cognitive thinking is defined in this study as the ability to find the interconnections between divergent ideas and the ability to synthesize that information as well as being open to emergent ideas.

\section{Integrate complex ideas}

Many of the presidents shared that their program enhanced their analytical thinking ability. For example, Nolan Cooper, a president of a large Historically Black University in the Southeast, expresses how he began making cognitive connections based on the complexity of higher education in his program.

I think what the curriculum in higher education did for me was to help me to gain greater insight into the complexity and the connectivity of issues in higher education. So, how finance is related to planning and planning is related to the ability to communicate effectively, how the ability to communicate effectively is related to one's analytical skills.

President Gavin Benjamin in the quote below explains how his doctoral experiences help him to view things strategically and incorporate multiple ideas to make a decision.

Probably in a strategic planning aspect of it and then, one of the best advantages was knowledge of what to expect. Making sure that my decisions are broad-based. My doctoral program helped me a great deal there.

\section{Intellectual flexibility}

Some presidents shared that they honed their intellectual capacity to integrate complex ideas in their doctoral program. For example, President Elijah Alexander said, "I really learned the complexity of higher education." 
Their programs also helped them prepare for future challenges within higher education. President Gavin Benjamin said it like this:

It helped me realize that over the course of my career things are going to change tremendously and I better be prepared to adapt. And not adapt just for myself and my administrative style, but adapt the institution to the change, too.

The participants shared that their programs challenged them to look at programs through different lenses. William James, an ivy-league doctoral educated president, adds that his program helped him develop ways in which to analyze complex problems.

The most important thing is to have an excellent skill set, analyzing issues and problems, and I certainly learned that in my graduate program. We were challenged on that all the time and so I think that's probably the most important skill set that I developed and continue to refine.

\section{Competencies}

In this study, competencies are defined as special non-generic skills that apply to a particular sector, job, or field. Competency areas the presidents identified as successfully preparing them for the presidency are displayed in Table 2 . The primary core competencies areas that presidents identified as important parts of their doctoral experience in terms of preparing them for the presidency included: Interpersonal Development, Personal Attributes, Management (Assessment/Accountability, Enrollment Management, Fundraising, and Strategic Planning), and Communication (Writing to diverse audiences and Speaking to diverse audiences).

Table 2. Competency Areas

\begin{tabular}{c}
\hline \multicolumn{1}{c}{ Competencies } \\
\hline Interpersonal Development \\
Personal Attributes \\
Management \\
- Assessment/Accountability \\
- Enrollment Management \\
- $\quad$ Strategic Planning \\
Communication \\
- Writing to diverse audiences \\
Speaking to diverse audiences
\end{tabular}

\section{Interpersonal Development}

The first competency area derived from this study is interpersonal development. Interpersonal development is defined in this study as the ability to relate and work with diverse individuals. More than half of the presidents expressed that interpersonal development was an important part of their success as leaders within the academy. Many attributed the enhancement of these competencies to the time they spent within their doctoral programs. In addition, some felt that their program facilitated that development by allowing them to interact with faculty from their program and from other universities at conferences. President Elliott expressed her experience this 
way: "[I] learned to listen in class and to interact with other people very positively ... I developed my cultural skills, my skills in diversity."

For many presidents, their doctoral programs served as a socialization mechanism into the academy. Presidents such as Nolan Cooper believed that their doctoral experiences helped prepared them to interact and negotiate at the senior level in higher education. Although most of the presidents had served in mid-level positions in higher education prior to their program, they stated that in graduate school they were familiar with only the types of institutions they had graduated from and served. Their graduate programs exposed them to colleagues and instructors with different backgrounds. Many of the presidents draw upon these experiences as they interact with various constituencies. Dr. Joshua Dillan had such an experience. He said,

Relationship building, so I'm in a cohort with 18 students from big schools, small schools all around the country. I see executives, all ambitious people, and figuring out how does one be a leader in that group, but also the common barrier was a really valuable experience. I also think I saw my higher education career was in small private elite colleges and so I mixed a lot with other people saw private elite colleges, but did not particularly have colleagues from big public institutions or big private research institutions or community colleges or Black colleges or colleges on the Native American reservations and so it really started to open my eyes up to the broader world of higher education that in a way has become very valuable to me as a president of a school, even though it is a small private college where my understanding of the market forces and higher education that has proved very valuable to me.

It appears from the presidents' responses that their higher education programs effectively served as environments that allowed them to interact and learn from people of diverse backgrounds. Their preparation also enabled them to transfer this knowledge into their presidential roles.

\section{Personal Attributes}

President Evelyn Aurora and twelve other presidents shared that they learned more about themselves, their own perspectives, and the perspectives of others as well as their own personal attributes through their programs. This learning included developing their own sense of autonomy, focusing on developing their personal and professional values and identity, self-esteem and maturity. Learning and identifying their own personal attributes permitted them to understand and perceive their work in a deeper way. President Aurora shares this personal example.

I learned about perspective, you know whatever perspective you have can influence the questions you ask, the people you interview, and the data you read. I learned about how decisions are not necessarily made following some of those paradigms that you study.

Personal attributes are unique competencies. Their uniqueness as competencies lies in that they are determined on an individual basis. Because every student comes in with specific strengths, limitations, weaknesses, and concerns, his or her personal attributes are refined individually and not necessarily refined in the classroom.

\section{Management}

The third competency area is management. This includes a diverse cadre of management areas. Presidents identified the areas of assessment and accountability of student learning, enrollment management, and strategic planning as areas for which their program did well in preparing them. The mastery of these management competencies enabled presidents to be prepared to take on challenging responsibilities after completing the doctorate, eventually preparing them for the presidency. 


\section{Assessment and accountability of student learning}

In the ACE (2007) study it was found that presidents who had earned a doctoral degree with a specialization in higher education felt more prepared to deal with assessment and accountability of student learning than presidents who earned doctorates in other disciplines. In this study, there were mixed responses to this question. Although a majority of the presidents stated that their programs prepared them in the area of student assessment, a minority of them expressed concerns about this area. This will be further discussed in the section on program weaknesses.

Speaking about the strength of this area, President Elijah Alexander said, "I think my program did a very good job of preparing (me) in the area of assessment." Dr. William James response concurred with President Alexander when he said:

In regard to assessment issues, I do feel that I had sufficient preparation for that issue in regard to my doctorate program. It's something that I'm knowledgeable about. It's something that is very important.

Many of the presidents spoke about assessment in student learning from this perspective. They agreed that they had been taught and understood the issues surrounding student learning and its importance within the academy. They coupled their understanding with their doctoral training in statistics and assessment. President Levi Carter's comments best represent this experience when he shared:

Some of the things (assessment and accountability of student learning) came out of a few of the courses that I took in educational research... as well as a few of the methodology courses I took.

\section{Enrollment management}

Twelve of the presidents responded that their programs addressed issues related to enrollment management. But many, such as President William James, mentioned that concepts related to this competency were not taught in isolation.

My program was helpful in identifying a number of issues like enrollment management and looking at strategies for that solution.

This statement reinforces a common theme found throughout the interviews that presidents reported that their programs did not teach various subject in isolation. They reported that their programs used a thematic approach that allowed their instructors to interweave common themes throughout various courses. This thematic approach assisted with refining the presidents' complex thinking, as in the case of President Nolan Cooper whose program focused on the issue of access within the enrollment management process. Cooper explained the approach his program took this way:

It [Cooper's doctoral program] addressed a broad issue such as access. So you can't talk and think about access without thinking about admissions and outreach and recruitment and marketing. We talked about access, so the issue was access not enrollment management. So, you were able to get to the issue of enrollment management by focusing on the theme of access.

\section{Strategic planning}

Six of the presidents expressed the belief that their doctoral programs prepared them well in the area of strategic planning. In this study, strategic planning is defined as the process in which a higher education institution engages to define its course of action to prepare for the future of the institution. Dr. Peter Johns best sums up the general response of the respondents. 
I got a good dose of strategic planning emphasis in my program in my higher education program and that has served me well.

Presidents expressed that having an understanding of the strategic planning process helped many of them develop a vision, share the vision, gain buy-in from various constituencies, implement the plan, and assess the results of the initiative. Many of the presidents were exposed to those concepts within their programs. President Emelia Lily shared that her strategic planning course had such a profound effect on her that she decided to change her emphasis area:

I took a course in strategic planning, and afterwards I ended up changing my doctoral program. I started out looking at college student development, but I realized that curriculum was not what I needed. What I needed was the higher education administration curriculum and so I transferred departments within the school of education.

\section{Communications}

Communications was one of the most talked about competency areas discussed by presidents within this study. Many remarked that the quality of a president's thinking and judgment is measured by faculty and other constituencies by the way presidents express themselves in both written and oral communication. Communication as a competency in this study was defined as the effective execution of written or oral communication.

\section{Writing}

One of the areas that participants felt was important to their competency development was the role that their programs played in enhancing their writing ability. Some described learning how to write a précis or an executive brief enhanced their competence in writing professionally. Presidents shared that their programs prepared them to write to multiple audiences, such as to an academic audience and to the general public. Several presidents such as Joshua Dillan believed that their dissertation writing really honed their competence in writing.

The dissertation piece was the most significant piece for me. Figuring out how to develop an hour-long topic, researching and writing it. (In the place) where I completed my dissertation work, I have gone on to chair and be on probably 20 dissertation committees.

President Nolan Cooper offered how writing assignments in his doctoral program enhanced his communication ability.

I think by having to write a précis, you know a short paper where you take a topic and this professor I had in higher education, he forced us to write whatever we were going to write; the analytical piece as well as the application piece in one page. You didn't have to observe any margins, you could single space, you could double space, but you could only use one page. I think that forced me to write in a very concise, clear, crisp kind of manner.

President Cooper and presidents such as Emelia Lily shared that their programs did a good job of teaching them how to write both to scholarly and practitioner audiences. Lily believed learning how to write a strong executive brief helped her effectively communicate in her administrative roles.

What I learned in my leadership course in my doctoral program was the ability to write a brief, an executive brief. We had to read a number of articles and we had to do no more than a page 


\section{Public speaking}

In addition to learning how to write to diverse audiences, six presidents talked about the role that their doctoral programs played in enhancing their public speaking ability. For example, Dr.

Gavin Benjamin, president of Conner State University, talked about how a particular class affected his opportunities to refine and hone his speaking ability.

Well, you would choose a particular topic, this was before computers so you had a file, you would take a copy of a particular topic out of the file, might be, let's see, international education and you review literature on that and make a presentation in the class about current issues in international education. Let's see, its small classes, have maybe six or eight people in the class. So, you'd do a fifteen or twenty minute presentation.

Presidents, such as Lucas Jacob, had to make a cognitive shift when beginning their doctoral program because they had not been accustomed to making many presentations in class. They found that these classroom experiences helped prepare them for the public role they play today. Jacob explains his classroom experiences this way.

Well, as you know in most graduate schools, there's a great deal of presentation work that is done. Very often the faculty member will come in and say ok, you're going to cover this and you're going to cover this, and you're going to cover this and your job is to go out and prepare the material and come back and present to your colleagues with the faculty member acting as devil's advocate and mentor. That was a learning approach that is not used typically in the undergraduate area, so it required a bit of a learning curve.

\section{Program Weaknesses}

Most presidents indicated that, although it was not the only element in their success, their higher education program played an integral role in their development. However, there were two areas in which the presidents expressed their opinion that their programs did not prepare them well: Fundraising and Student Assessment.

\section{Fundraising}

As it related to the competency of fundraising, all presidents felt that their program did not prepare them to be competent in this area. This corresponds with the results of the secondary analysis of the 2007 ACE study. President Lucus Jacob of Landon State put it best and succinctly when he said, "There's nothing in the graduate program that prepares you for fund raising. Absolutely nothing!!"

This is an important finding because many of the presidents stated that they spend a lot of time on fundraising. They indicated that they either learned fundraising through professional experiences or through conferences or workshops or on the job.

Prior to earning their doctorate some of the presidents served as mid-level administrators where fundraising was not the focus of their work. However, once in senior level positions many had to learn how to fundraise on the job. Although many felt that workshops and conferences on fundraising helped them prepare for these issues, they expressed the belief that their academic experience should have addressed preparation for fundraising. Some presidents suggested that case studies and role-play activities could prepare students for these opportunities.

President Nolan Cooper provided some unique descriptions of how fundraising could be incorporated into the curriculum.

The best way to get the experience I think is to have a foundation executive come in and spend some time at a fund raising seminar with doctoral students. Another example 
would be to require students to write a successful proposal. So, your task if you have a group of twenty people in the classroom would be to put them in groups of five and assign one group a request like you have to write a proposal to establish a new center on health disparities and, don't tell them what the foundations are-that's your task. Another one would be to write a proposal for student persistency to graduation, another one community outreach and diversity, and another one may be the restoration of historic buildings on campus. Give the person some background information about the institution, give them a case study, but the product would need to be a proposal that could be submitted to a foundation and you actually have the foundation executives come into the classroom and go through the proposal and say, here are the things that we found good about it, not so good about it, you could've blah, blah, blah. That's how the curriculum can address fundraising.

\section{Assessment and accountability of student learning}

Although, as reported earlier, the majority of presidents felt prepared to deal with issues of student assessment and accountability, there were others such as President Ryan Wyatt from MicahHenry University who felt that not enough time was not spent on these issues. He shared:

We did not spend a lot of time on outcomes and the issues related to programmatic accountability that are so important in higher education today.

President William James seconded this notion when he said:

In regard to assessment issues, I do feel that I had sufficient preparation for that issue in regard to my doctorate program. It's something that I'm knowledgeable about. It's something that is very important.

Although all presidents did not feel that their program prepared them as well as it should in the area of assessment of student learning, all believed that the issue of accountability and assessment of student learning was important. Several mentioned that external constituencies such as lawmakers and regional accreditation agencies are holding presidents responsible for student outcomes.

\section{Discussion}

Although the findings of this study may not be generalizable to all situations, they do provide insights that may be useful for those involved in developing and implementing academic programs and professional experiences for current and aspiring university presidents. The discussion of these findings will address these insights in terms of implications for curriculum, policy, and practice.

\section{Curricular Implications}

One of the most powerful outcomes of this study was the finding that presidents believed that it was very important to include foundational courses and information related to history and finance in higher education doctoral programs curriculum. They further indicated that their programs had done a good job in this regard. These results are similar to Herdlein's (2004) study of the perceptions of chief student affairs officers in that executive higher education knowledge and competencies can be developed around the areas such as acquisition of knowledge, which includes mastering and implementing the knowledge that is developed. Although most universities seem to include these types of courses, this is one of the first studies that verifies that what is being taught in this area is meaningful to graduates in the presidency and, therefore, should be continued. 
When comparing the results of this study to the results of Herdlein's (2004) study unique distinctions emerge. In this study, president's perceived that higher education programs positively affected the development of their knowledge and competencies in the areas of finance and budgeting, strategic planning, assessment and accountability, and writing, whereas chief student affairs believed higher education programs underprepared students in those areas. However, there was agreement across both studies as related to higher education programs positively preparing leaders in general knowledge about higher education and understanding human differences. Although Herdlein's (2004) study utilized a larger sample size and quantitative methods to conduct his study, his results are informative as they relate to the impact that higher education graduate programs can have on its graduates.

The results also suggest that programs should integrate information and ensure that students are given opportunities to develop intellectual flexibility, meaning that they are open and able to address competing ideas and ideologies. Faculty teaching on management topics, such as assessment and accountability of student learning, enrollment management, fundraising, and strategic planning, should attempt to interweave these as themes throughout the curriculum. This will help students develop the intellectual flexibility and cognitive complexity to address the tough issues they are bound to face in either faculty or administrative roles

Data from this study also suggest that presidents developed strong interpersonal competencies while in their program. This implies that programs should ensure that their faculty and students have diverse backgrounds, so that students can learn how to interact with individuals with differing perspectives. The study also alludes to the notion that higher education programs should create a learning environment in which students can explore and enhance their personal attributes.

Overwhelmingly, presidents mentioned that their programs helped them develop competence in communication. This indicates that higher education programs should continue to give their students diverse assignments using both oral and written communication formats to ensure that graduates are prepared to communicate with diverse audiences.

A surprising outcome of this study is that, in general, presidents did not address issues related to emerging technologies or diversity in terms of the changing demographics of the times - areas that many higher education researchers say the presidents must address now and into the future (Farrington, 2008; Jaschik, 2007; Lum, 2008, 2009). It may be that they are comfortable in these areas, but do not view their preparation programs as being a part of developing their knowledge. It may also be that technology is not something they view as in their purview. This area requires further research. This finding and the finding related to the need to prepare presidents for fundraising activities point to the fact that the curriculum in higher education cannot be static. Program leaders will need to constantly be thinking about the changing demands in higher education and determine ways to best prepare their students for those realities.

These presidents often spoke about the need for both theoretical and practical knowledge in order to succeed. Yet, it is very difficult for programs to have topical experts on staff in all areas that must be taught. Likewise, with changes in the environment and the role of the universities and the presidency undergoing changes because of the complexities of our global society, even if faculty have had experience as practitioners, these practitioners may have been in faculty positions and out of the administrative for many years. Since this is the case, it might be wise for programs to engage and partner with field-base practitioners, particularly program alumni to augment their knowledge and expertise. These partnerships can take the form of guest lectureships and adjunct or visiting professorship appointments. In addition, higher education programs could invite experts on topics of cutting-edge research from other institutions. Engaging in such activities has become more practical with the advent of distance technologies, which would allow programs to invite guest lecturers from around the world to participate in sharing research or practical advice. 
These individuals could be invited to serve as affiliate faculty in the higher education program and offered opportunities to serve on thesis and dissertation committees as well.

Universities may also want to consider creating advisory councils composed of practitioners to help review and revise curricular offerings and to serve as mentors and role models for students. In addition to helping strengthen the relationship between theory and practice, these types of activities will help to assure that the curriculum will include topics relevant to those preparing for the presidency.

\section{Policy and Practice Implications}

This study provides important insights that may be able to be incorporated into policy and practice by executive higher education programs such as the University of Pennsylvania, Jackson State University, and University of Georgia. These are programs that are specifically geared to training executive level higher education administrators. This is particularly timely as such programs are developing around the country. Standard higher education doctoral programs can also incorporate these findings into their curriculum. This study also has policy implications for fieldspecific organizations such as the Council for the Advancement of Higher Education Programs and Council for the Advancement of Standards in Higher Education as they grapple with identifying, sharing, and implementing standards to improve higher education curriculum across the fields programs.

Another constituency that may glean insights from this research is non-degree granting higher education training agencies. These agencies include organizations such as the American Council of Education, Harvard Institute for Educational Management, and Kellogg Minority Serving Institutions (MSIs) Leadership Fellows Program. As suggested for executive and standard higher education doctoral programs, non-degree granting higher education training agencies may want to consider incorporating the knowledge and competencies identified in this study into their conference and workshop curriculum for senior leadership in higher education.

\section{Suggestions for Future Research}

Since this study included only university presidents, it would be relevant in the future to explore the perspectives of presidents of other institutions, such as for-profit institutions, community colleges, and liberal arts institutions. It might also be meaningful to conduct research with university presidents who had earned their doctorate in a discipline other than education. These presidents could provide insights into how and if the discipline they earned a doctorate in helped to prepare them for their first presidency and whether they perceive their preparation any differently than presidents in this study.

It would be fruitful for research to be conducted on the quality and effectiveness of differing types of experiences such as classes, practicum and internships, and case studies to determine whether presidents view any of them as being more viable in enabling them to acquire needed knowledge and skills within higher education programs. A study on this topic could provide higher education faculty and curriculum developers with information that could assist them in enhancing the quality of higher education practice.

It would also be important for research to be explored related to best practices of teaching the knowledge, skills, and competencies suggested in this study. In addition, data should be collected that provides higher education faculty and curriculum developers with information on how to best assess the mastery of the knowledge and competencies. This would also help higher education faculty and curriculum developers as they seek to design effective curriculum for their programs. 
It may also be valuable to explore best practices in teaching the knowledge, skills, and competencies suggested in this study. In addition, data should be collected that provide higher education faculty and curriculum developers with information on how to best assess the mastery of the knowledge and competencies. This would also help higher education faculty and curriculum developers as they seek to design effective curriculum for their programs.

\section{Conclusion}

It is important that those entrusted with teaching future leaders, particularly those preparing university presidents, teach those students how to acquire the knowledge and competencies that they need to succeed in the $21^{\text {st }}$ century. Although most university presidents do not move straight from their doctoral programs to a presidency, it is important that students be exposed to the knowledge base and competencies needed for senior leadership prior to arriving in that position. Clearly, more research is needed to find out whether higher education programs adequately prepare presidents from other institutional types, but this study provides a useful starting point for higher education graduate program development and for future research in that realm and in other areas.

\section{References}

Altbach, P. G., Bozeman, L. A., Janashia, N., \& Rumbley, L. E. (2006). Higher education: A worldwide inventory of centers and programs (revised edition). (Commercial edition published by SensePublishers, Rotterdam, the Netherlands).

Altbach, P., \& Engberg, D. (2001). Higher education: A worldwide inventory of centers and programs. Phoenix: Oryx Press.

The American Council on Education. (2007). The American college president: 2007 edition. Washington, DC.

The Association for the Study of Higher Education's Council for the Advancement of Higher Education Programs (CAHEP). (2010). A commitment to quality: Guidelines for higher education administration and leadership preparation programs at the master's degree level. Retrieved from http://www.ashe.ws/images/CAHEPLeadershipProgramGuidelines.pdf

Austin, A. E. (2002). Preparing the next generation of faculty: Graduate school as socialization to the academic career. The Journal of Higher Education, 73, 94-121.

Baliles, G. L. (2006). The leadership imperative (1st ed.). Washington, DC: The Association of Governing Boards of Universities and Colleges.

Barnett, N. (2007). Higher education as a field of study at Historically Black Colleges and Universities. Doctoral dissertation, Ball State University, Indiana. Retrieved April 29, 2011, from Dissertations \& Theses: A\&I (Publication No. AAT 3288300).

Bray, N. J. (2007). Curriculum: An overview. In D. Wright \& M. Miller (Eds.), Training higher education policy makers and leaders: A graduate program perspective (pp. 111-121). Santa Barbara, CA: Information Age/Greenwood Publishing.

Brown, P. A. (2008). Presidential leadership: Understanding the influence of academic disciplines. Public Purpose, 9-13.

Campbell, M. S. (1999). Using a life history approach to explore the identity of a woman diagnosed with Alzheimer's disease: The life of Mary. M.S. Thesis, Virginia Polytechnic Institute and State University, Blacksburg, VA. Retrieved from http://scholar.lib.vt.edu/theses/available/etd-061599132826/unrestricted/SEAN3.pdf

Charmaz, K. (2006). Constructing grounded theory: A practical guide through qualitative analysis. London: Sage. 
The Council for the Advancement of Standards in Higher Education (CAS). (2006). CAS general guidelines. Retrieved from http://www.cas.edu/index.php/cas-general-standards/

Creswell, J. W. (1998). Qualitative inquiry and research design: Choosing among five traditions. Thousand Oaks, CA: Sage Publications.

Dressel, P. L., \& Mayhew, L. B. (1974). Higher education as a field of study. San Francisco, CA: JosseyBass.

Ellis, E. M. (2001). The impact of race and gender on graduate school socialization, satisfaction with doctoral study, and commitment to degree completion. The Western Journal of Black Studies, 25, 30-45.

Farrington, E. L. (2008). Strategies to reach gender parity in college presidents. Women in Higher Education. Retrieved from http://www.whihe.com/printBlog.jsp?id=19251

Fife, J. D., \& Goodchild, L. F. (Eds.). (1991). Administration as a profession. San Francisco, CA: JosseyBass.

Gardner, S. K. (2010). Keeping up with the Joneses: Socialization and culture in doctoral education at one striving institution. The Journal of Higher Education, 81(6), 728-749.

Gasman, M., \& Anderson-Thompkins, S. (2003). A renaissance on the eastside: Motivating inner-city youth through art. Journal of Education for Students Placed at Risk, 8(4), 429-450.

Gonzalez, J. C. (2006). Academic socialization experiences of Latina doctoral students: A qualitative understanding of support systems that aid and challenges that hinder the process. Journal of Hispanic Higher Education, 5(4), 347-365.

Goodchild, L. F. (2002). Higher education as a field of study. In J. J. F. Forest \& K. Kinsner (Eds.), Higher education in the United States (pp. 303-309). Santa Barbara: ABC-CLIO.

Hammons, J. O., \& Miller, M. T. (2006). Presidential perceptions about graduate-preparation programs for community colleges. Community College Journal of Research and Practice, 30(4), 373-381.

Haynes, C., Bulosan, M., Citty, J., Hudson, J., \& Koro-Ljungberg, M. (2012). My world is not my doctoral program...or is it? Female students' perceptions of well-being. International Journal of Doctoral Studies, 7, 1-17. Retrieved from http://ijds.org/Volume7/IJDSv7p001-017Haynes329.pdf

Herdlein, R. J., III. (2004). Survey of chief student affairs officers regarding relevance of graduate preparation of new professionals. NASPA Journal, 42(1), 51-71.

Holley, K. (2011). A cultural repertoire of practices in doctoral education. International Journal of Doctoral Studies, 6, 79-94. Retrieved from http://ijds.org/Volume6/IJDSv6p079-094Holley312.pdf

Jaschik, S. (2007). The graying of the presidency. Inside Higher Ed. Retrieved from http://www.insidehighered.com/layout/set/print/news/2007/02/12/presdata

Knowledge. (n.d.). In Oxford Dictionaries online. Retrieved from http://oxforddictionaries.com/view/entry/m_en_us $1261368 \# \mathrm{~m}$ en_us 1261368

Keim, M. C. (1991). Student personnel preparation programs: A longitudinal study. NASPA Journal, 28(3), 231-242.

Kienle, A. W., \& Loyd, N. L. (2005). Globalization and the emergence of supranational organizations: Implications for graduate programs in higher education administration. College Student Journal, 39(3), $580-587$.

Leech, N. (2012). Educating knowledgeable and skilled researchers in doctoral programs in schools of education: A new model. International Journal of Doctoral Studies, 7, 19-37. Retrieved from http://ijds.org/Volume7/IJDSv7p019-037Leech325.pdf

Lum, L. (2008). Forming a pipeline to the presidency. Diverse Issues in Higher Education, 25(7).

Lum, L. (2009). Asian-Americans hope to build pipelines to college presidencies. Diverse Issues in Higher Education. Retrieved from http://diverseeducation.com/cache/print.php?articleid=13097 
Luxton, A. (2005). Higher Education Quality Management in Higher Education Management Series Number 2. Commissioned by the Department of Education General Conference.

Ross, M. E., \& Shannon, D. M. (2008). Applied quantitative methods in education. Dubuque, IA: Kendall/Hunt Publishing Company.

Sandeen, A. (1982). Professional preparation programs in student personnel services in higher education: A national assessment by chief student affairs officers. NASPA Journal, 22(1), 51-58.

Selingo, J. (2003). The making of the college president. Chronicle of Higher Education, 49(22), 40.

Soto-Anthony, J. (2002). Reexamining doctoral student socialization and professional development: Moving beyond the congruence and assimilation orientation. In J. C. Smart (Ed.), Higher education: Handbook of theory and research (XVII, pp. 349-380). New York, NY: Agathon.

Stuver, A. L. (2006). A graduate student's expectation of graduate education. Retrieved from www.aps.org/programs/education/upload/StuverCalTec.pdf

Wolfe, B. (2010). When being black isn't enough: Experiences and persistence strategies of six African American administrators at a PWI. Doctoral Dissertation, Auburn University, Alabama. Retrieved from Dissertations \& Theses: A\&I (Publication No. AAT 3446190).

Weidman, J., Twale, D., \& Stein, E. (2001). Socialization of graduate and professional students in higher education: A perilous passage? San Francisco: John Wiley \& Sons.

Wright, D. (2004). Career objectives of students majoring in higher education leadership. Unpublished manuscript.

Wright, D. (2007). Progress in the development of higher education as a specialized field of study. In D. Wright \& M. Miller (Eds.). Training higher education policymakers and leaders: A graduate perspective (p.19-34). Charlotte, NC: Information Age.

Wright, D., \& Miller, M. (Eds.). (2007). Training higher education policymakers and leaders: A graduate perspective. Charlotte, NC: Information Age Publishing.

Yin, R. K. (2003). Case study research, design and methods (3rd ed.). Newbury Park: Sage Publications. 


\section{Appendix A: ACE's American College President's Study American Council on Education \\ American College President's Survey 2006

Chief Executive Officer (CEO) Identifying Information

1. Name:

2. Position title:

(1) President/CEO/chancellor

(2) Senior executive/provost/dean

(3) Other:

3. Phone:

a. Fax:

b. E-mail:

c. UNITID: 101514

Your Current Position

4. As CEO, to whom do you report?
(1) System head
(2) Governing board
(3) State commissioner/superintendent/church official/other

5. Date appointed to current CEO position ( $\mathrm{mm} / \mathrm{yy})$ :

6. Is the position an interim appointment?
(1)
Yes
(2)
No

7. Do you hold a tenured faculty position at this time?
(1)
Yes
(2) No

\section{Prior Positions}

8. How many college or university CEO positions have you held prior to your current position?

9. Position held immediately prior to assuming current CEO assignment:
(1) President/CEO/chancellor
(2) Chief academic officer or provost
(3) Other senior executive in Academic Affairs (including deans)
(4) Senior executive in Development
(5) Senior executive in External Affairs (e.g., government relations)
(6) Senior executive in Student Affairs
(7) Senior executive in Finance and/or Administration
(8) Chair/faculty
(9) K-12 administrator/educator
(10) Business/industry
(11) Religious counselor/member of religious order
(12) Elected or appointed government official
(13) Legal professional
(14)—Military personnel
(15) Medical professional (e.g., doctor or hospital administrator)
(16) Nonprofit sector (e.g., foundation, museum, or association)
(17) Other:

d. Institution of position held immediately prior to assuming current CEO assignment:
(1) _ Same institution as current job
(2) Different institution from current job
(3) _ Not applicable (e.g., worked in business, government)

e. For how many years did you hold that position?

f. Did you have tenured faculty status at that time?
(1) Yes
(2) No
(3) Not applicable

10. Position held prior to the position described in item 9:
(1)
(2) President/CEO/chancellor
Chief academic officer or provost
(3) _ Other senior executive in Academic Affairs (including deans)
(4) Senior executive in Development 
(5) Senior executive in External Affairs (e.g., government relations)

(6) Senior executive in Student Affairs

(7) Senior executive in Finance, and/or Administration

(8) Chair/faculty

(9) K K-12 administrator/educator

(10) Business/industry

(11) Religious counselor/member of religious order

(12) Elected or appointed government official

(13) L Legal professional

(14) Military personnel

(15) Medical professional (e.g., doctor or hospital administrator)

(16) Nonprofit sector (e.g., foundation, museum, or association)

(17) Other:

g. Institution of position held prior to the position described in item 9:
(1) Same institution as current job
(2) Same institution as prior job described in item 9
(3) Different institution from both current and prior job described in item 9
(4) Not applicable (e.g., previously not employed in higher education)

h. For how many years did you hold that position?

i. Did you have tenured faculty status at that time?
(1)
Yes
(2)
No
(3)
Not applicable

\section{Career History}

11. Have you ever altered your job circumstances to care for a dependent or spouse?

(1) Yes; left the job market

(2) _ Yes; worked part time/reduced schedule

(3) Yes, other

(4) No

j. If yes, how many years did you alter your job circumstances?

12. Over the course of your professional career, how many years were you employed full time outside higher education?

13. How many years have you served as a full-time faculty member at a college or university?

14. Before your first presidency, in how many presidential searches were you invited for an interview?

\section{Your Education}

15. Please check all the degrees you have earned:
(1) Associate
(2) Bachelor's
(3) Master's
(4) PhD
(5) $\quad$ EdD
(6) MD
(7) Other health degree (e.g., DDS, DVM)
(8) Law (e.g., JD, LLB, LLD, JSD)
(9) Other (e.g., theology, doctor of ministry, master of divinity). Please specify:

16. Indicate major field of study for your highest earned degree:
(1) Agriculture/natural resources
(2) Biological sciences
(3) Business
(4) Education or higher education
(5) Engineering
(6) Health professions
(7) Humanities/fine arts 


\begin{tabular}{|c|c|}
\hline (8) & Law \\
\hline (9) & Mathematics \\
\hline (10) & Medicine \\
\hline (11) & Physical/natural sciences \\
\hline (12) & Religion/theology \\
\hline (13) & Social sciences \\
\hline
\end{tabular}

17. If you earned a bachelor's degree, did you receive it from a single-sex college?
(1) Yes
(2) No

18. Have you ever taken formal training or been certified as a religious professional?
(1)
Yes
(2) No

\section{Your Background}

19. Gender:
(1)
Male
(2)
Female

20. Year of birth: 19

21. Are you Hispanic or Latino(a)?
(1)
Yes
(2) _ No

22. What is your race/ethnicity? (Check all that apply).

(1) White

(2) African American

(3) Asian/Pacific Islander

(4) American Indian/Alaskan Native

(5) Other (please specify):

23. Are you a citizen of the United States of America?
(1) Yes, born in the United States
(2) Yes, born in Puerto Rico, Guam, the U.S. Virgin Islands, or Northern Marianas
(3) Yes, born abroad of American parent or parents
(4) Yes, a U.S. citizen by naturalization
(5) No, not a citizen of the United States

24. Marital status:
(1)
(2)
(3)
(4)
(5)
(6)
(7)

Never married (m
Never married
Married
Domestic partner
Separated
Divorced
Widower/widow

25. Do you have children?
(1)
Yes
(2)
No

k. If yes, do you have children under the age of 18 ?
(1)
Yes
(2)
No

26. Please indicate your religious preference:
(1) Buddhist
(2) Christian (Protestant)
(3) Christian (Roman Catholic)
(4) Jewish
(5) Muslim
(6) Other (please specify):
(7) None

27. Besides English, can you speak any languages at least somewhat?
(1) Yes
(2) No 


\section{The Search and Acceptance Process}

28. Was a search consultant used in the search that resulted in your selection for this presidency?
(1)
Yes
(2)
No

29. Before accepting the position, did you seek advice in negotiating the terms of employment?
(1)
Yes
(2) No

I. If yes, whom did you consult for advice? (Check all that apply.)
(1) Attorney
(2) Colleagues in the field of higher education
(3) Colleagues outside of higher education
(4) Financial planner/accountant/other financial expert
(5) Other (please specify):

30. Do you have a written contract?
(1)
Yes
(2)
No

m. If yes, what is the length of this contract?

31. Do you feel that the search process disclosed to you:

n. A realistic assessment of the current status of the institution?
(1)
Yes
(2)
No

o. A full and accurate disclosure of the institution's financial condition?
(1)
Yes
(2) No

p. A clear understanding of the CEO's role?
(1)
Yes
(2) _ No

q. A clear understanding of your spouse or domestic partner's role, if applicable?
(1)
Yes
(2) — No
(3)
Not applicable

r. A clear understanding of the board's expectations?
(1)
Yes
(2)
No

s. A clear understanding of the institution's expectations?
(1)
Yes
(2)
No

32. Which of the following are parts of your agreed-upon conditions of employment? (Check all that apply.)
(1) Automobile (without a driver)
(2) Driver and automobile
(3) Parking
(4) Consulting opportunities
(5) Paid corporate directorships
(6) Deferred compensation
(7) Pension/retirement contributions
(8) Performance-based bonuses
(9) Salary increase based on merit
(10) _L Loan at no or low interest
(11)_Presidential house
(12) Housing allowance
(13) House manager
(14)_Housekeeper
(15) _Entertainment budget
(16) Life insurance
(17) Health insurance (currently)
(18) Health insurance (retiree)
(19) _ Professional financial planning assistance
(20) ___ Membership fees for clubs
(21) Membership dues for professional associations
(22) Evaluation (expectations for performance, when and how evaluation will occur)
(23) _ Executive coaching 
(24) ___ Involuntary separation agreement

(25) Relocation (moving expenses for self and family)

(26) Retention (time-based) bonuses

(27) Sabbaticals

(28) __ Tuition assistance for family members

33. Please describe the employment status of your spouse or domestic partner. (Check all that apply.)

(1) Compensated by institution for role as host, fund raiser, and/or spouse or domestic partner

(2) Employed at your institution, in capacity not related to president

(3) _ Unpaid participant in campus activities

(4) Employed outside of your institution

(5) _ Not applicable, no spouse or domestic partner

34. Which of the following are parts of your agreed-upon conditions of employment for your spouse or domestic partner, separate from your benefits? (Check all that apply.)

(1) Assigned staff person(s)

(2) Automobile (without a driver)

(3) Driver and automobile

(4) Parking

(5) Pension/retirement contributions

(6) Life insurance

(7) Membership fees to clubs

(8) Travel budget

(9) Not applicable, no spouse or domestic partner

35. In which of the following areas did you feel insufficiently prepared for your first presidency? (Check all that apply.)
(1) Academic issues (e.g., curriculum changes)
(3) Athletics
(4) _Budget/financial management
(5) Capital improvement projects
(6) Community relations
(7) Crisis management
(8) Enrollment management
(9) Entrepreneurial ventures
(10) Faculty issues
(11) _ Fund raising
(12) Governing board relations
(13)_Government relations
(14) Media/public relations
(15) Personnel issues (excluding faculty)
(16) Risk management/legal issues
(17) _ Strategic planning

\section{Your Duties and Institution}

36. Select the top three areas that you enjoy working in the most as a college president.
(1) Academic issues (e.g., curriculum changes)
(2) Accountability/assessment of student learning
(3) Athletics
(4) Budget/financial management
(5) Capital improvement projects
(6) Community relations
(7) Crisis management
(8) Enrollment management
(9) Entrepreneurial ventures
(10) _ Faculty issues
(11) _ Fund raising
(12) __ Governing board relations
(13) __ Government relations
(14) _ Media/public relations
(15) Personnel issues (excluding faculty)
(16)_ Risk management/legal issues 


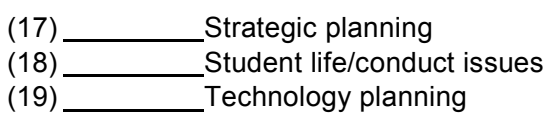

37. Select the top three areas that occupy most of your time.
(1) Academic issues (e.g., curriculum changes)
(2) Accountability/assessment of student learning
(3) Athletics
(4) Budget/financial management
(5) Capital improvement projects
(6) Community relations
(7) Crisis management
(8) Enrollment management
(9) Entrepreneurial ventures
(10)_ Faculty issues
(11) Fund raising
(12)_Governing board relations
(13) Government relations
(14) Media/public relations
(15) _ Personnel issues (excluding faculty)
(16) Risk management/legal issues
(17) Strategic planning
(18) Student life/conduct issues
(19)_ Technology planning

38. Select the top three constituent groups that provide the greatest reward to you as president.

(1) Administration and staff

(2) Alumni/ae

(3) Community residents/leaders

(4) Donors/benefactors

(5) Faculty

(6) Governing board

(7) Legislators and policy makers

(8) Media

(9) Parents

(10) Students

(11) System office or state coordinating board

39. Select the top three constituent groups that present the greatest challenge to you as president.

(1) Administration and staff

(2) Alumni/ae

(3) Community residents/leaders

(4) Donors/benefactors

(5) Faculty

(6) Governing board

(7) Legislators. and policy makers

(8) Media

(9) Parents

(10) Students

(11) $\_$System office or state coordinating board

40. Since becoming president, do you perform any of the following regularly? (Check all that apply.)
(1) Conduct research in your academic discipline
(2) Teach a course by yourself
(3) Team teach a course
(4) Write for scholarly publication in your academic discipline

41. Do you currently serve on any external boards?
(1) Yes
(2) No

t. If yes, how many of these boards are (please specify number):

(1) Corporate

(2) College or university

(3) Other nonprofit organizations 

(1)
Yes
(2)
No

43. How important are the following faculty issues to your institution?

u. Recruiting new faculty

(1) Very important

(2) Somewhat important

(3) Not important

v. Retaining existing faculty

(1) Very important

(2) Somewhat important

(3) Not important

w. Retiring older faculty

(1) Very important

(2) Somewhat important

(3) Not important

44. Has your institution introduced any incentives to encourage older faculty to retire?
(1) Yes, a phased retirement program
(2) Yes, an early retirement program
(3) Yes, other programs/policies
(4) No
(5) Unsure

$x$. If yes, has the program been effective in increasing retirement rates?
(1)
(2)
(3) Too early to determine
(4) Unsure

45. Has your institution introduced any initiatives to attract female and/or minority faculty?'
(1) Yes; initiatives to attract female faculty
(2) _ Yes, initiatives to attract minority faculty
(3) Yes, initiatives to attract both female and minority faculty
(4) No
(5) Unsure

46. In the next five years, do you expect the percentage of your institution's total revenue from each of the sources listed below to increase, decrease, or stay the same?

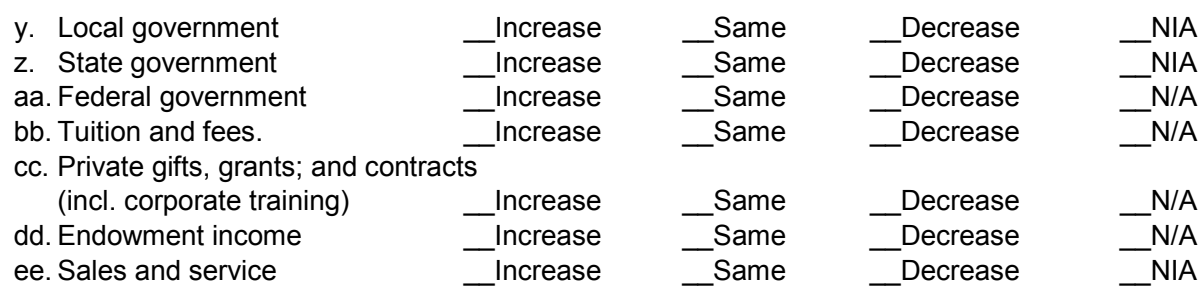

47. In the next five years, do you expect the enrollment at your institution to increase, decrease, or remain the same?

$$
\text { _Increase _ Same _Decrease _NIA }
$$

48. Did you begin your very first presidency prior to December 31, 1995 ?
(1) Yes
(2) No

ff. If yes, please continue to the special focus section on the next page. If no, you have completed the survey, thank you.

\section{Special Focus Section: The Changing Role of a College President}


49. Select the top three areas that have increased in their level of importance since you first became a college president.
(1) Academic issues (e.g., curriculum changes)
(3) Athletics
(4) Budget/financial management
(5) Capital improvement projects
(6) Community relations
(7) Crisis management
(8) Diversity
(9) Enrollment management
(10) Entrepreneurship
(11) Faculty issues
(12) Fund raising
(13) Governing board relations
(14) Government relations
(15) Media/public relations
(16) Operating costs (e.g., health-care, energy)
(17) Personnel issues (excluding faculty)
(18) Risk management/legal issues
(19) Strategic planning
(20) Student life/conduct issues
(21) Technology planning

50. Select the top three trends/reasons listed below that best explain why the role of the college president has changed in the past 10 years
(1) Decline in state funding
(2) Demographic shifts and increasing racial/ethnic diversity of students and employees
(3) Erosion of public trust and confidence
(4) Increased competition among institutions
(5) Increased expectation of entrepreneurship
(6) Increased focus on private benefit of higher education in place of com-
mon good of higher education
(7) Increasing litigiousness of American society
(8) Political polarization of American society
(9) Technological advancements
(10) Twenty-four hour news cycle
(11) Other

51. Which broad constituent group did you spend the majority of your time interacting with when you first became a college president?
(1)
(2) Internal audience (your institution)'
(3) Spent equal time on both internal and external

52. Today, which broad constituent group do you spend the majority of your time interacting with as a college president?
(1)
(2)
(3)
Internal audience, (your institution)
External audience
Spent equal time on both internal and external

53. Would you say you spend more time, less time, or the same amount of time on the following issues today than you did when you first became a college president?

\begin{tabular}{|c|c|c|c|c|}
\hline $\begin{array}{l}\text { Academic issues } \\
\text { (e.g., curriculum changes) }\end{array}$ & _More $^{\text {Mor }}$ & __Same & _Less $^{\text {Les }}$ & ${ }^{\mathrm{N} / \mathrm{A}}$ \\
\hline $\begin{array}{l}\text { Accountability/assessment } \\
\text { of student learning' }\end{array}$ & _ More & _ Same & _Less $^{\text {Les }}$ & ${ }^{\mathrm{N}} \mathrm{A} / \mathrm{A}$ \\
\hline Athletics & _More & __Same & _Less & $-\mathrm{N} / \mathrm{A}$ \\
\hline Budget/financial management & _More & _Same & _Less & $\ldots$ N/A \\
\hline Capital improvement projects & _ More & _ Same & _Less & $\ldots$ N/A \\
\hline
\end{tabular}




\begin{tabular}{|c|c|c|c|c|}
\hline Community relations & _More & __Same & LLess & $\ldots \mathrm{N} / \mathrm{A}$ \\
\hline Crisis management & _More & _Same & LLess & $\ldots \mathrm{N} / \mathrm{A}$ \\
\hline Diversity & __More & __Same & LLess & $\ldots \mathrm{N} / \mathrm{A}$ \\
\hline Enrollment management & _More & __Same & LLess & $\ldots \mathrm{N} / \mathrm{A}$ \\
\hline Entrepreneurship & _ More & __Same & LLess & $\ldots \mathrm{N} / \mathrm{A}$ \\
\hline Faculty issues & _ More & __Same & LLess & $-\mathrm{N} / \mathrm{A}$ \\
\hline Fund raising & _More & _Same & LLess & $\ldots$ N/A \\
\hline Governing board relations & __More & __Same & Less & $\ldots \mathrm{N} / \mathrm{A}$ \\
\hline Government relations & _More & _Same & _Less & $\ldots \mathrm{N} / \mathrm{A}$ \\
\hline Media/public relations & _More & __Same & LLess & $\ldots \mathrm{N} / \mathrm{A}$ \\
\hline $\begin{array}{l}\text { Operating costs } \\
\text { (e.g., health-care, energy) }\end{array}$ & __More & _ Same & —Less $^{\text {Les }}$ & ${ }_{-}^{N} / \mathrm{A}$ \\
\hline Personnel issues (excluding faculty) & _More & _Same & LLess & $\ldots \mathrm{N} / \mathrm{A}$ \\
\hline Risk management/legal issues & __More & __Same & Less & $\ldots \mathrm{N} / \mathrm{A}$ \\
\hline Strategic planning & _ More & _ Same & LLess & $-\mathrm{N} / \mathrm{A}$ \\
\hline Student life/conduct issues & _ More & _ Same & LLess & $-\mathrm{N} / \mathrm{A}$ \\
\hline Technology planning & _ More & _Same & _Less & $\ldots$ N/A \\
\hline
\end{tabular}

Thank you for completing this survey.

Please fold survey, staple closed and drop in the mail.

The survey is also available online at http://survey.acenet.edu/Scripts/rws3.pl?FORM=ACPS 


\section{Appendix B: Qualitative Interview Questionnaire}

1. Let's go back to the time before you started your doctoral program.

a. Why did you decide to seek a terminal degree in higher education administration?

b. When did you decide to pursue a doctorate, at what stage in your career?

c. What was your long term professional objective?

d. Did you believe that your degree would prepare you for that vocation?

Probe: In the back of your mind, did you think that your degree would prepare you for a future presidency?

2. Now I'd like to ask about your experience as a doctoral student.

a. Please share with me some of the skills and competencies you learned and developed while studying in your higher education administration doctoral program.

b. In the ACE study, when asked whether they were sufficiently prepared for fundraising activities, presidents with doctoral degrees in education or higher education felt less prepared than those from other disciplines. What is your reaction to this finding? Did your program address issues of fundraising and, if not, how could that have better incorporated into the curriculum?

Probe: Would you suggest using the Indiana University HEA program model? Is fundraising a topic that needs to be offered as a cognate or certificate?

c. It was also found in the ACE study that those with doctoral degrees in education or higher education felt more prepared to manage issues of accountability and assessment of student learning than presidents from other disciplines. Did you feel the same way in your first presidency and if so how did your doctoral program prepare you to deal with issues of accountability and assessment?

Probe: If not, why?

d. The study also noted that those who earned a doctoral degree in education or higher education felt better prepared in addressing issues related to enrollment management. Did your doctoral program address issues related to enrollment management and, if so, how has that informed your practice today?

3. Did your program have a internship or practicum experience? If so, did you participate?

Probe: Why did you decide not too?

a. How did attendance at professional conferences and memberships in professional societies assist in your professional development?

4. Now I would like to ask you a few questions about your current job

a. How have the skills and competencies introduced back in your doctoral program shaped the way you perform your duties today?

5. What are the core competencies needed for today's college or university president across level and type?

6. Can you give examples of skills or knowledge that you have learned on-the-job as president? 
7. How has professional development training programs such as the Harvard Institute for Educational Management, ACE's Presidential Roundtable, or the Kellogg MSI Leadership Fellows Program, assisted in your skill development?

Probe: Could you elaborate on that? Please describe specific skills you have learned.

8. Now I would like to ask you a few questions about higher education programs in general

a. How would you describe an effective higher education doctoral program?

Probe: Please describe expectations of faculty, curriculum, and students.

9. Please provide examples of skills or competencies you would advise students of develop while in their higher education programs?

(Interviewer note: use suggestions from ACE list. Suggestions include the following: assessment of student learning, enrollment management, media, public relations etc.)

Probe: And what would be the best way to facilitate those skills? What techniques would you advise faculty to use? i.e. Case studies, Simulations, Role Play, internships, etc. (Interviewer note: Don't give examples unless asked for)

10. What should I have asked you, but did not? 


\section{Biographies}

Sydney Freeman Jr. is the Director of the Teaching and Learning Center in the College of Vet-

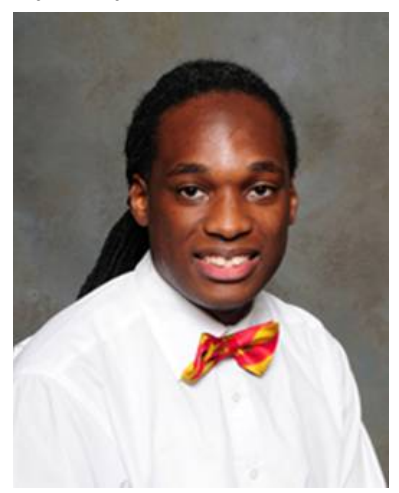
erinary Medicine, Nursing, and Allied Health at Tuskegee University. His research interests include Higher Education as a Field of Study, the University Presidency, and Minority Serving Institutions. He had previously served as the Assistant Editor of the Journal of School Leadership and currently holds an affiliate faculty appointment within the Adult and Higher Education program at Auburn University. He also serves as the chair of the Ad Hoc Committee on Higher Education Leadership Program Guidelines which is under the Council for the Advancement of Higher Education Programs and affiliated with Association for the Study of Higher Education. He earned a Bachelor's at Oakwood University and a masters and Ph.D. at Auburn University.

Frances K. Kochan is a Wayne T. Smith Distinguished Professor in Educational Leadership at

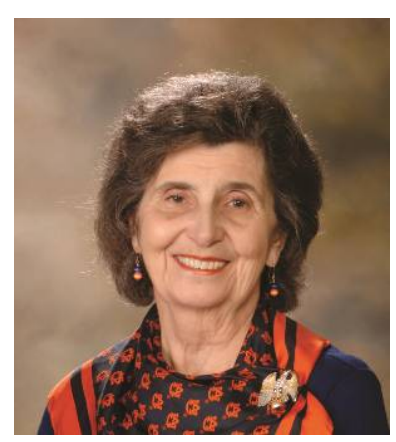

Auburn University where she has been for 16 years. She served as dean of the college for 8 years. Prior to holding that position she served as Associate Dean and as Director of the Truman Pierce Institute, a research and outreach center in the college. Prior to coming to Auburn, Dr. Kochan was Director/ Superintendent of the Florida State University School and was an affiliated associate professor in the Educational Leadership department. She has worked as an associate superintendent, principal and teacher in a number of school systems and also served as project director for numerous innovative projects. Dr.

Kochan holds a Ph.D. from Florida State University, a Masters from the University of Guam, and a Bachelor's from the State University of New York at Fredonia. She served on the UCEA Board and is a past UCEA president. She chaired the AERA SIG on Mentoring and was a member of the International Mentoring Association and the Holmes Partnership Boards. Dr. Kochan conducts research on mentoring, organizational change, and on forming collaborative relationships between schools, universities and communities. She has edited or co-edited five books and published almost 70 articles on these topics. 